\title{
A holocene pollen and charcoal record from a tropical lowland swamp in Rawa Danau, West Java, Indonesia
}

\author{
Eko Yulianto $^{1 *}$, Hiroyuki TsujI ${ }^{1)}$, Woro Sri SukAPTI ${ }^{2)}$ and Noriyuki TANAKA ${ }^{3)}$ \\ ${ }^{1)}$ Graduate School of Environmental Earth Science, Hokkaido University, Kita-ku, Kita 10, Nishi 5, Sapporo 060-0810, Japan \\ ${ }^{2)}$ Laboratory of Quaternary Geology, Geological Research and Development Center, J1. Dr. Junjunan 236 Bandung 40174, Indonesia \\ ${ }^{3}$ Frontier Research System for Global Change, Yokoyama City, Kanagawa, Japan \\ "Corresponding Author: Tel; +81-11-706-2275, E-mail; Ekoy001@yahoo.com
}

\begin{abstract}
A pollen and charcoal record of a core from the Rawa Danau peat swamp in Central West Java provides a picture of environmental change and fire history from $c a$. $7400 \mathrm{yr}$ BP. This record also verifies the results of a previous study on the causes of change in lignin-phenols along the core. Woody peat has been accumulating at the site along the core. The record demonstrates that vegetation change occurred in the area as a response to climatic and environmental changes, as well as human disturbances. In addition, charcoal particles in peat indicate that fire occurred in this area throughout the period. Initially, the site was a swamp forest with numerous open areas from $c a$. 7400-6500 yrs BP. Vegetation in the Rawa Danau appears to have been stable during the period from $c a$. 6500 to 3800 years BP. Subsequently, open herbaceous swamp developed in the area from $c a .3800$ to 2300 years BP as indicated by the preponderance of Gramineae. Dry climatic conditions with lower effective precipitation than that of the previous period prevailed during this period. This is correlative with regional climatic conditions at this time. The dry climatic conditions facilitated intensive fire, as indicated by the high $\mathrm{C} / \mathrm{P}$ value in the pollen record. From $c a .2200 \mathrm{yr}$ BP, the vegetation of the Rawa Danau swamp might have been more or less similar with the present vegetation. During the last 200 years, the vegetation in the Rawa Danau area became more open as a consequence of the significant increase in human disturbances. In addition, changes in lignin phenols (LPVI values) of the Rawa Danau core have been caused by changes in the proportion of Gramineae rather than that of the gymnosperms.
\end{abstract}

Key words: climate change, fire, human disturbance, vegetation change

\section{INTRODUCTION}

Pollen records are important for understanding environmental changes and evolution. These records provide evidence for vegetation change and, by inference, the climatic and sea-level changes, and human disturbances. In the Indonesian tropics, pollen studies have been frequently used to understand Holocene environmental changes, particularly in high altitude sites, which are sensitive to changes in temperature, and in coastal sites, which are sensitive to changes in sea level. Despite the many pollen records during the Holocene from high altitudes (e.g. Newsome and Flenley, 1988; Stuijts, I., 1993; Van der Kaars and Dam, 1995) and coastal sites (e.g. Anderson and Muller, 1975; Caratini and Tissot, 1988; Yulianto et al., 2004), there are very few terrestrial lowland records available and the palaeoenvironmental development of the Indonesia lowlands remains poorly understood.

This paper presents a pollen record of Holocene environmental change from Rawa Danau, West Java, Indonesia. Although Late Quaternary palaeoecological and palaeoclimatic records of the site were described by Van der Kaars $e t$ al. (2001), they failed to provide adequate information of the Holocene period due to relatively low sampling resolution. On the other hand, Tareq et al. (2004) reported Holocene vegetation changes in site based on biomarker signatures and explained that changes in biomarker signatures have been mainly caused by changes in the relative proportion of gymnosperms and angiosperms. The pollen record presented in this study will confirm this interpretation and reveal Holocene vegetation and environmental evolution in the Rawa Danau area.

\section{THE STUDY SITE}

Rawa Danau is a nature reserve on the western tip of Java that consists of freshwater lakes and swamps. The reserve lies at an elevation of $192 \mathrm{~m}$ above sea level (asl), in a caldera of a Plio-Pleistocene volcanic complex on the western tip of Java Island, Indonesia (Fig. 1). The elevation of the surrounding volcanic terrain ranges from 400 to $700 \mathrm{~m}$ asl. The several rivers that originate in the surrounding hills flow to the main river, the Cidanau River. The Cidanau River originates in the 
northern lower slopes of the Karang volcano and flows across the Rawa Danau swamp to the Sunda Strait, about $5 \mathrm{~km}$ to the west of the area. The sediment of the swamp consists of fine grained lake deposits (organic silty clay and silty gyttja with shells), with minor intercalations of peat and fluvial sands (Rimbaman, 1994). Peat deposits prevail in the central swamp area with sequences of up to 4-5 m thickness just below the surface. The annual precipitation of the study area is about $2500 \mathrm{~mm}$ and temperatures range daily from 17 to $25^{\circ} \mathrm{C}$.

The area consists of mixed swamp forest, Ficus retusa swamp forest and open herbaceous swamp, whereas dry land and upper mountainous areas are largely covered by deciduous plants with conifers, depending on altitude. Detailed descriptions of the vegetation of the area have been made by Van der Kaars et al. (2001).

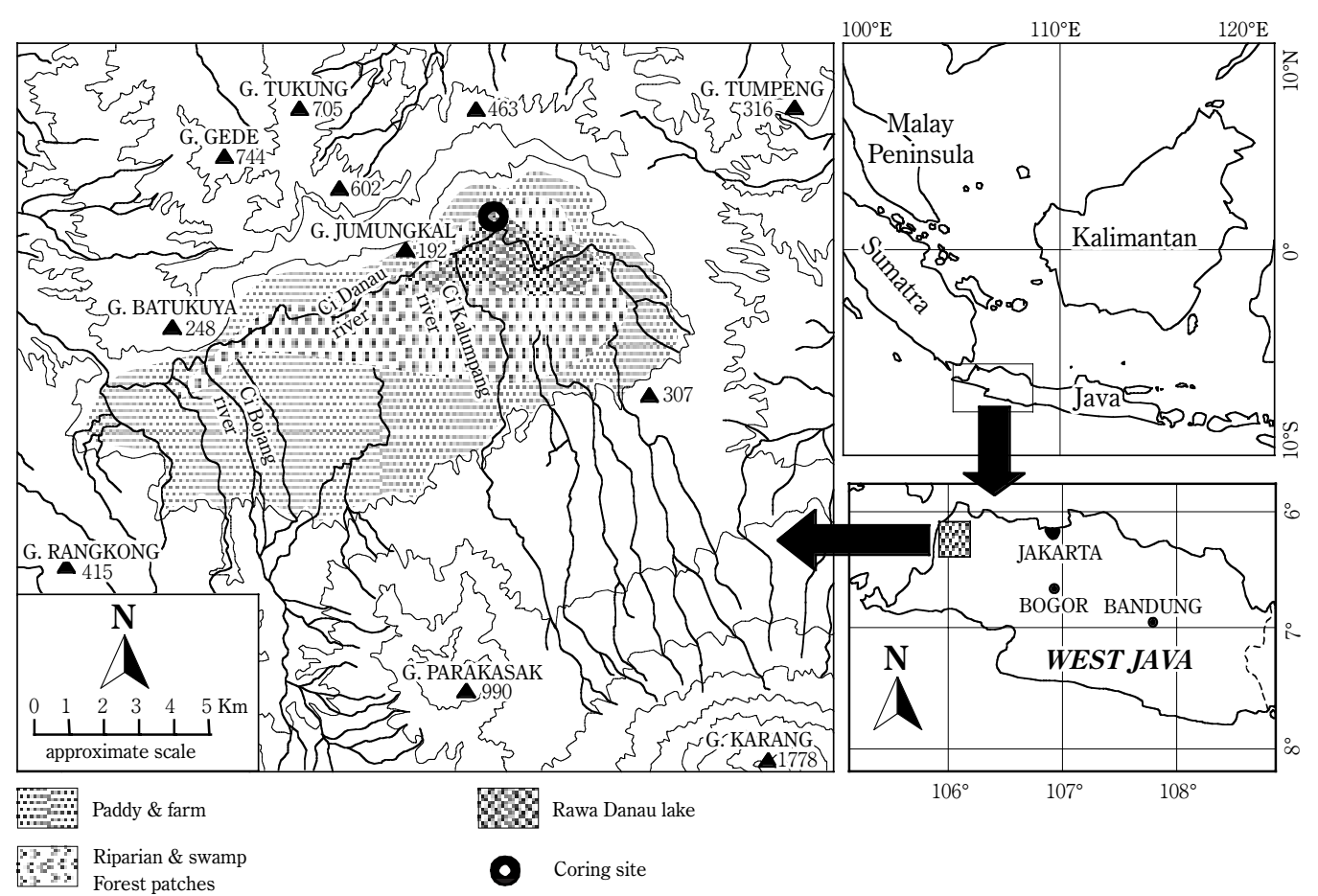

Fig. 1. Map of the study area showing the core site and topographic contours.

\section{FIELD AND LABORATORY METHODS}

A $360 \mathrm{~cm}$ core (RD-1) was collected by piston coring. Three short test cores were collected for site selection. The core was taken from the northwestern corner of the Rawa Danau caldera (Fig.1) where the greatest thickness of peat deposits was found. One gravity sub-core of $32 \mathrm{~cm}$ was collected to maintain the sedimentary sequence, because the top section of the RD-1 core was disturbed. For pollen analysis, two $\mathrm{cm}$ slices of the core were taken at $8 \mathrm{~cm}$ intervals along the length of core. Two $\mathrm{cm}^{3}$ was extracted from each slice for pollen analysis.

Each sample was initially treated with $10 \% \mathrm{KOH}$ before the mixed-acid treatment $\left(\mathrm{HCl}+\mathrm{HNO}_{3}\right.$ with $1: 1$ proportion). The residue was then treated with heated $10 \% \mathrm{KOH}$ before sieving to remove larger fragments. The remaining organics were separated from mineral matter using $\mathrm{ZnCl}_{2}$ heavy liquid, before the $40 \% \mathrm{HF}$ treatment to remove silica. Dissolution of cellulose substances was accomplished by 1-minute acetolysis. The remaining organic residue was washed using distilled water and submerged in glycerol for 30 minutes. After decantation, a few drops of glycerin jelly were mixed in with the residue before mounting on microscope slides.

Pollen counts were made on a LOMO microscope at a magnification of X 400. Initial identification was verified using an X 100 oil immersion objective, giving a magnification of X 1000. All the pollen grains present in the sample were counted. Pollen and spore frequencies were calculated as the sum of total pollen and presented in a pollen diagram. The diagrams were zoned with the aid of a stratigraphically constrained classification cluster analysis (ConsLink) contained within the POLPAL program. All taxa were used as input into ConsLink.

Radiocarbon dating was conducted using the ${ }^{14} \mathrm{C}$ AMS method. Dates were calibrated to calendar years using the 
program CALIB rev.4.3 (Stuiver and Reimer, 2000). Ages of samples between the dated points were estimated by linear interpolation.

Micro-charcoal analysis was conducted using the pollen-slide method. In this method, the number of charcoal particles is counted on the slides prepared for pollen analysis. All black, opaque, angular and $>10 \mu \mathrm{m}$ in size particles were counted as charcoal. The results of micro-charcoal analysis were presented as charcoal/pollen ratio ( $\mathrm{C} / \mathrm{P}$ ratio). The $\mathrm{C} / \mathrm{P}$ ratio is defined as the percentage of charcoal particle to charcoal and pollen sum.

\section{RESULTS}

\section{Stratigraphy and Chronology}

The core (RD-1) consists of woody peat with several intercalating ash layers. The upper $50 \mathrm{~cm}$ of the core was a mixture of grass-woody peat and partially decayed plant tissues. A volcanic ash layer was observed at 8-12 cm depth.

Table 1. Radiocarbon dates from Rawa Danau core. Calendar ages were calculated using CALIB 4.3 (Stuiver and Reimer, 2000). Calendar age in years BP, AD/BC, and 2 $\sigma$ range are given.

\begin{tabular}{ccccc}
\hline \multirow{2}{*}{$\begin{array}{c}\text { Sample } \\
\text { Code }\end{array}$} & $\begin{array}{c}\text { Depth } \\
(\mathrm{cm})\end{array}$ & $\begin{array}{c}\text { Uncalibrated Ages } \\
\text { (years B. P.) }\end{array}$ & $\begin{array}{c}\text { Cal. Ages, } 2 \sigma \\
\text { (years B. P. }\end{array}$ & $\begin{array}{c}\text { Cal. Ages, 2 } \sigma \\
\text { (AD/BC) }\end{array}$ \\
\hline RDT2 & 22 & $410 \pm 240$ & 353 & AD 1600 \\
RDT3 & 55.5 & $880 \pm 220$ & 858 & AD 1098 \\
RDT4 & 66.9 & $1040 \pm 280$ & 974 & AD 976 \\
RDT5 & 99 & $1400 \pm 260$ & 1310 & AD 640 \\
RDT6 & 123.2 & $1600 \pm 290$ & 1548 & AD 402 \\
RDT7 & 137.6 & $1740 \pm 350$ & 1704 & AD 246 \\
RDB1 & 175.3 & $3030 \pm 260$ & 3287 & BC 1338 \\
RDB2 & 188.3 & $3500 \pm 360$ & 3800 & BC 1851 \\
RDB3 & 207.7 & $4020 \pm 360$ & 4455 & BC 2506 \\
\hline
\end{tabular}

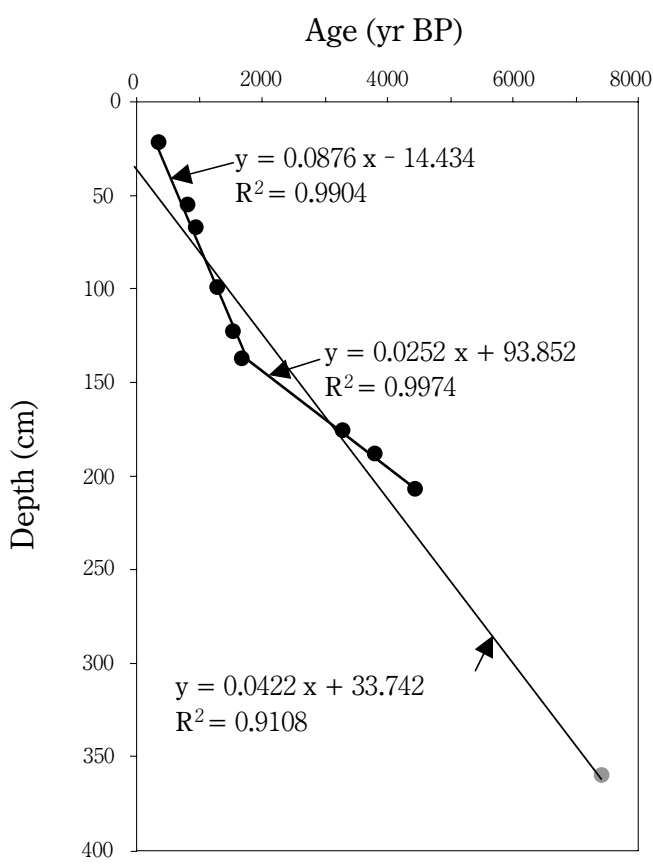

Fig. 2. Age/depth relationship of dated samples. The lowermost grey dot is the extrapolated age and straight lines are the regression linears. 
Nine samples were taken for radiocarbon dating. The dates are presented in Table 1. The core covers a period from $c a$. 7400 yrs BP (Before Present) to the present. The linear regression of the dates $\left(\mathrm{y}=0.0422 \mathrm{x}+33.742 ; \mathrm{R}^{2}=0.9108\right)$ suggests that the deposition rate was approximately $0.048 \mathrm{~cm} / \mathrm{yr}$ during the Holocene at Rawa Danau. Our sampling interval $(8 \mathrm{~cm})$ results in a temporal resolution of $c a .160 \mathrm{yrs}$. However, the sedimentation rate of the core seems not to have been uniform. The sedimentation rate was approximately $0.004 \mathrm{~cm} / \mathrm{yr}$ from 140 to $200 \mathrm{~cm}$ depth $\left(\mathrm{y}=0.0876 \mathrm{x}-14.434, \mathrm{R}^{2}=\right.$ 0.9904), while it was about $0.08 \mathrm{~cm} / \mathrm{yr}$ above $140\left(\mathrm{y}=0.0252 \mathrm{x}+93.852, \mathrm{R}^{2}=0.9974\right)$ (Fig. 2$)$

\section{The Pollen Diagram}

Pollen and charcoal data, along with the core stratigraphy and radiocarbon dates, are shown in Fig. 3. The ConsLink dendogram distinguished 5 zones.

Zone 1 (360-325 cm depth; ca. 7400-6500 years BP)

The pollen diagram of Zone 1 is characterized by the prominence of Castanopsis/Lithocarpus, Croton, Dacrycarpus, Meliaceae, Polygonum and Gramineae. Acalypha, Aglaia, Avicennia, Blumeodendron, Elaeocarpus, Sapotaceae and Calamus. Other pollen types are present in lesser abundance. Among the fern spores, Stenochlaena palustris, Aspleniaceae and Polypodiaceae are common. The $\mathrm{C} / \mathrm{P}$ ratio is low and slightly increases toward the top.

\section{Zone 2 (325-200 cm depth; ca. 6500-3800 years BP)}

Castanopsis/Lithocarpus, Ilex, Meliaceae, Pometia and Randia are prominent in Zone 2. The abundance of Avicennia increases from the bottom of the zone and decreases at the top. Salacca is highly abundant, although sporadically. Blumeodendron, Calamus, Croton, Dacrycarpus, Elaeocarpus, Gramineae and Polygonum, which are present in the previous zone, are absent or nearly absent. Euphorbiaceae, Ilex and Randia, which are absent or nearly absent in the previous zone, are prominent in Zone 2. Some pollen types such as Mallotus, Saxifragraceae, Stemonurus, Sterculiaceae, Tilia, Cucurbita and Stenochlaena palustris are more abundant than in the previous zone. The C/P ratio, which is higher than the previous zone, shows a peak around $300 \mathrm{~cm}$ depth, and decreases toward the top.

Zone 3 (200-130 cm depth; ca. 3800-2300 years BP)

The prominence of Gramineae characterizes this zone. Eugenia, Castanopsis/Lithocarpus, Euphorbiaceae, Ilex, Meliaceae, Pometia, Randia and Sapotaceae are less represented than in the previous zone. Pteris increases at the bottom of the zone and shows little representation at the top. Croton, Dacrycarpus, Durio, Elaecarpus and Rhizophoraceae, which are almost absent from the previous zone, are present at the top of Zone 3. A significant increase of Pteridophyte spores occurs at 136 $\mathrm{cm}$. The $\mathrm{C} / \mathrm{P}$ ratio is high along the zone and slightly decreases toward the top.

\section{Zone 4 (130-30 cm depth; ca. 2200-200 years BP)}

This zone is characterized by the prominence of Salacca. Ilex, Pometia, Randia and Stemonurus. Caesalpinia, Croton, Dacrycarpus, Durio, Elaeocarpus and Rhizophoraceae are absent. Gramineae, which has decreased from the previous zone, shows little representation in this zone. Cyathea, Stenochlaena palustris and Polypodioaceae show slight decreases at the middle of the zone. Other pollen types are present in small numbers. The $\mathrm{C} / \mathrm{P}$ ratio is lower than in the previous zone and increases toward the top.

\section{Zone 5 (30-0 cm depth; ca. 200-0 years BP)}

Salacca is prominent, but in less numbers than in the previous zone. Gramineae is more abundant than in the previous zone. Ilex, Randia and Stemonurus are present in substantial numbers. Pometia, Calamus and Compositae show a significant increase only at the top of the zone. Cyathea, Polypodiaceae and Stenochlaena palustris are more abundant than in the previous zone. The $\mathrm{C} / \mathrm{P}$ ratio is high along the zone.

\section{DISCUSSION}

\section{Vegetation and Environmental Reconstruction}

The earliest period, Zone 1, covers a period from 7400-6500 yrs BP. During this period, Aglaia, Castanopsis/Lithocarpus, Dacrycarpus, Meliaceae and Sapotaceae are important components in the forest around the Rawa Danau Lake. The high representation of shrub and herb pollen types, such as Croton, Gramineae, Polygonum and Rosaceae, indicates the presence of an open environment. New land might have emerged in the perimeter of the lake if lake shallowing had occurred. Results of diatom analysis in a previous study provide evidence for this (Van der Kaars et al., 2001). It is likely that shrub and herb vegetation might have developed on this new land. The mangrove pollens discovered here, such as Avicennia, 


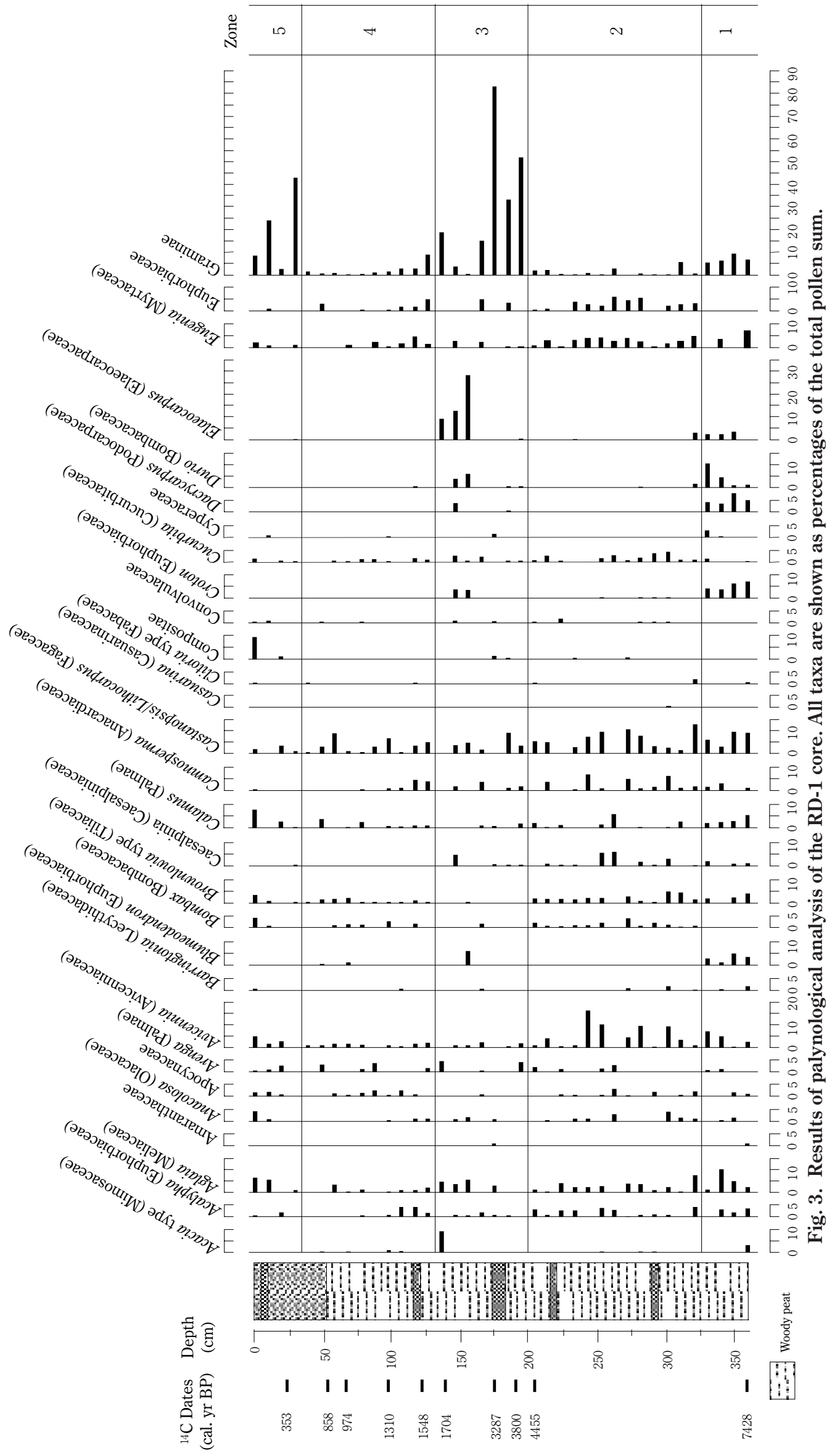




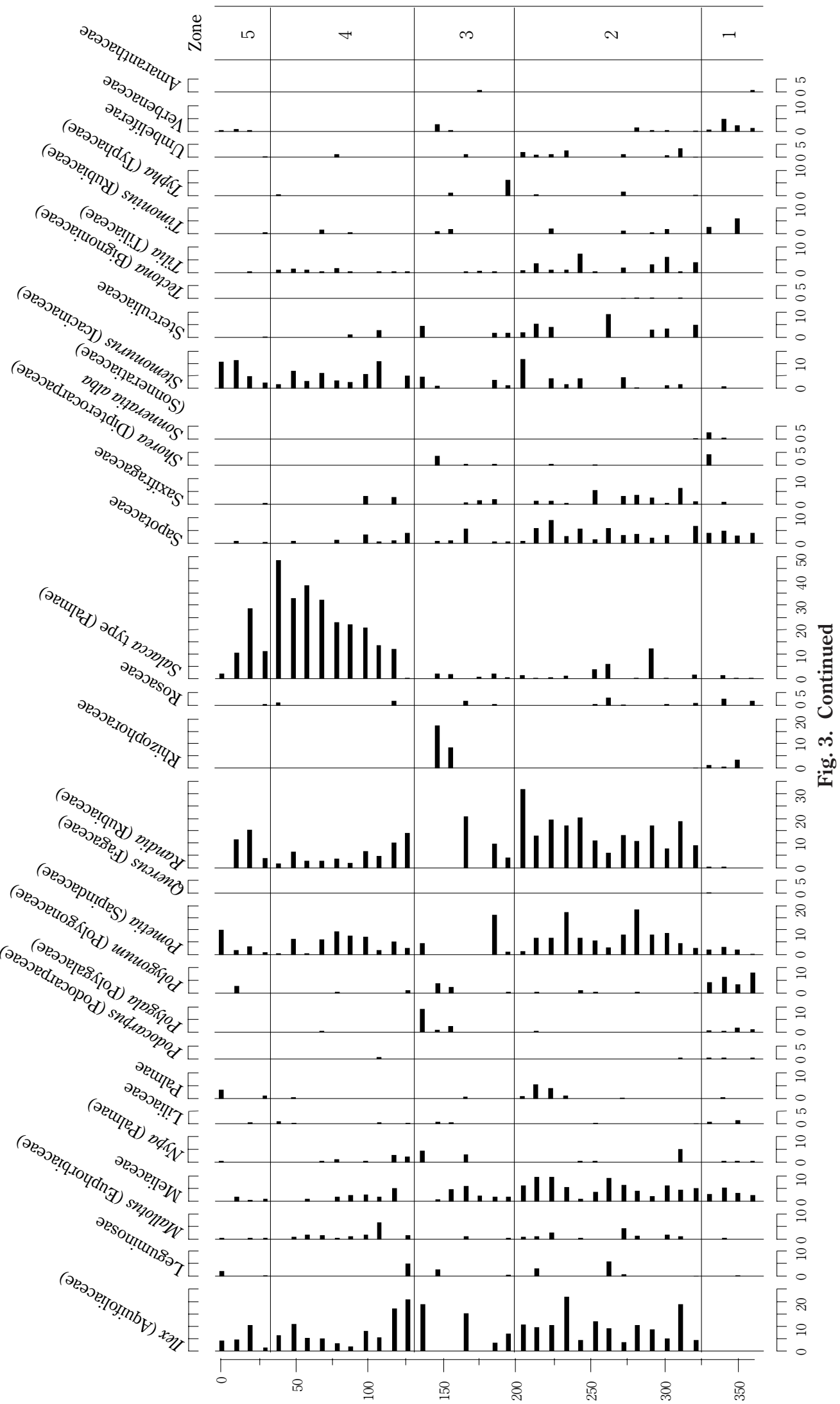




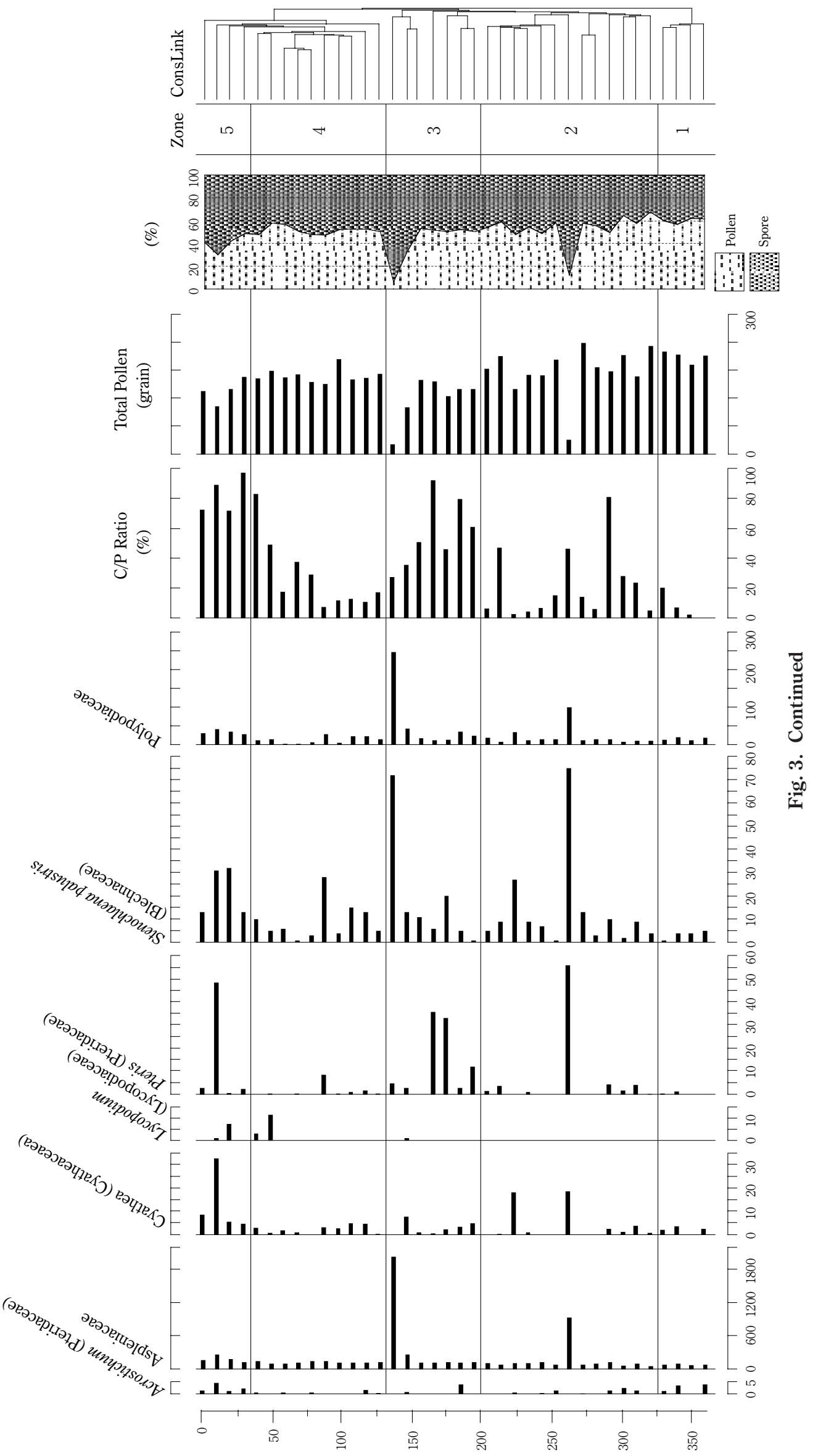


Rhizophoraceae and Sonneratia alba, must have been transported long-distance, indicating the development of mangrove vegetation in the Sunda Strait area.

Vegetation in the Rawa Danau appears to be stable during the period from ca. 6500 to 3800 years BP. The forest communities were dominated by Castanopsis/Lithocarpus, Ilex, Meliaceae, Pometia and Randia with Eugenia and Sapotaceae as minor elements. The great abundance of Avicennia, a mangrove element, reflects maximum expansion of mangrove vegetation in the Sunda Strait around the mid-Holocene. This might correlate with the Holocene transgression that may have inundated estuaries, channels, and depressions in Sunda Strait, resulting a broadening of mangrove areas. Many palynological studies on marine and coastal sediments in the region show a similar pattern, with maximum expansion of mangrove elements in the Early Holocene (Gremmen, 1990; Van der Kaars, 1991, 1998; Van der Kaars et al., 2000; Yulianto et al., 2004). The increase of $\mathrm{C} / \mathrm{P}$ values around $300 \mathrm{~cm}$ depth indicates increased fire frequency. The fires might be small, because there is almost no significant change in pollen values, and they could be attributed to the increase in anthropogenic activity around the Rawa Danau swamp.

Open herbaceous swamps developed from ca. 3800 to 2300 years BP, as indicated by strong presence of Gramineae and low representation of tree pollen types. Increased human disturbances might have occurred concurrently with the onset of slightly drier climatic conditions. As a result, forest cover was reduced and herbs, such as Gramineae, and shrubs, such as, Ilex, Pometia, Randia and Stemonurus, became important elements in the vegetation. On the other hand, the precipitation might have been significantly lower than that of the previous times, as also indicated by the lower sedimentation rate. The drier climatic conditions might have facilitated intensive fire. The high $\mathrm{C} / \mathrm{P}$ value in the pollen record at this time provides some corroborative evidence of increased fire frequency and intensity. This also indicates an increase of anthropogenic activity in the Rawa Danau swamp. In addition, extensive development of Gramineae might have been facilitated by the emergence of new land in the perimeter of the lake due to further lake shallowing as reported in a previous study (Van der Kaars et al., 2001). Reasons for the increase in the abundance of Elaeocarpus at the upper zone and a sudden increase of pteridophyte spores at the uppermost level are unclear.

High representation of Salacca sp., probably Salacca edulis, along with substantial representation of shrubs, particularly Ilex, Mallotus, Randia and Stemonurus, from ca. 2200 and 200 years BP indicates the persistence of relatively open vegetation around the lake in this period. The vegetation of the Rawa Danau swamp might have been more or less similar to the present vegetation where relatively open vegetation is present around the lake in the swamp forest and a dense undergrowth of Salacca is common in the hilly forest (Van der Kaars et al., 2001).

During the last 200 years, the vegetation in the Rawa Danau area became more open as indicated by the high representation of herbs, shrubs and ferns, such as Gramineae, Compositae, Salacca, Ilex, Calamus, Cyathea and Stenochlaena palustris. These plants are present prominently in the open areas around the lake (Van der Kaars et al., 2001). Therefore, human disturbance must have increased significantly during this time. The abundance of Gramineae and $\mathrm{C} / \mathrm{P}$ values support this interpretation. Prevalent Gramineae pollen types in the pollen record may have derived partly from cultivated rice paddy, while high charcoal reflects an intensification of burning activity.

\section{Verification of Biomarker Data Interpretation on Vegetation Change}

Tareq et al. (2004) have reported on the lignin phenol ratio of the core used in this study. They proposed a Lignin Phenol Vegetation Index (LPVI) based on lignin phenols. Fig. 4 shows the LPVI curve of their study. They explained that changes in the LPVI of the Rawa Danau core indicate changes in vegetation in the Rawa Danau area. A low LPVI reflects a high proportion of gymnosperm, while a high LPVI reflects a high proportion of angiosperms in the vegetation community. Accordingly, elevated LPVI values at 27.7, 76.1, 117.1 and $175.3 \mathrm{~cm}$ depth result from the presence of more angiosperms relative to gymnosperms.

However, there is no clear evidence of gymnosperms in pollen records. The only gymnosperms recorded in sediment are Dacrycarpus and Podocarpus. Their pollen values are very low, indicating that they were not local vegetation. Therefore, peat material of gymnosperm origin must have been very scarce in sediment and not likely to contribute significantly to lignin phenols in the sediment. Moreover, those taxa are montane taxa that grow only above $1000 \mathrm{~m}$ elevation at present (Van der Kaars, 1991). Their presence in the lowland swamp of Rawa Danau area would indicate a drop of atmospheric temperature. These taxa were not found as local vegetation in the Rawa Danau area even during the last glacial maximum (Van der Kaars et al., 2001) when the sea surface temperature in the tropics was $2.5-3.0^{\circ} \mathrm{C}$ lower than today at modern sea level. 


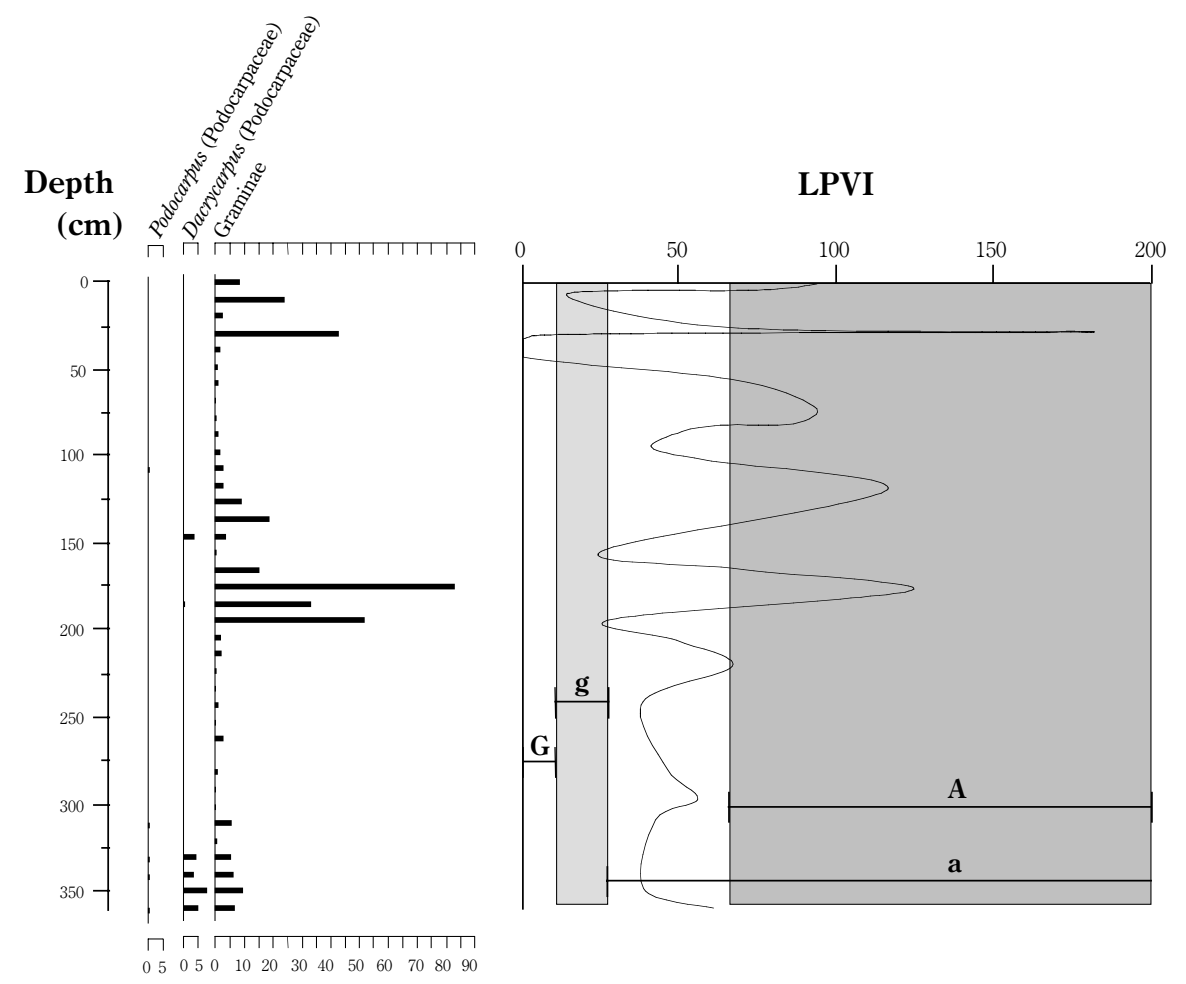

Fig. 4. Values of gymnosperms (Podocarpus and Dacrycarpus) and Gramineae, and LPVI with an illustration of ranges for gymnosperm $(\mathrm{G})$, non-woody gymnosperm (g), angiosperm (A), non-woody angiosperm (modified from Tareq et al., 2004). This figure shows that there is no correlation between LPVI values with relative proportion of gymnosperms. Instead, there is an indication of correlation between LPVI values with Gramineae values.

Comparing the LPVI curve with the pollen record, there is no correlation between changes in LPVI values with changes in the proportion of gymnosperms to angiosperms. Instead, elevated LPVI values seem to correlate well with the increased proportion of Gramineae (Fig. 4). Accordingly, changes in lignin phenols of the Rawa Danau core might have been caused by changes in the abundance of Gramineae, rather than that of the gymnosperms. This implies that LPVI values may be a good indicator of changes in Gramineae abundance and, by inference, succession from arboreal to non-arboreal vegetation. However, this explanation needs further examination.

\section{Regional Comparison}

Changes in the palaeoenvironmental record at the local level (Rawa Danau area) clarify Holocene vegetation and environment changes and human disturbance in the lowland area of Indonesia. Moreover, this analysis is a useful addition to the Holocene pollen and charcoal record, as there is only limited pollen and charcoal records from lowland areas of the region.

All samples contain micro-charcoal fragments. These fragments provide clear evidence that fire occurred frequently in the Rawa Danau area since ca. 7500 yr BP. This also indicates that the Rawa Danau area has experienced human disturbance since thousands of years ago. Fluctuation in the $\mathrm{C} / \mathrm{P}$ ratio, however, points to differing scales of fire and human disturbances. Two peaks of the C/P value were identified at ca. 0 200 yr BP $(0-80 \mathrm{~cm})$ and ca. 2300 3800 yr BP $(150-200 \mathrm{~cm})$. The C/P value peak at ca. 0 200 yr BP $(0-80 \mathrm{~cm})$ depth obviously demonstrates a marked intensification of land use in the Rawa Danau area. The southern part of the area is now cleared for rice field and villages (Van der Kaars et al., 2001). A charcoal peak at 2300 3800 yr BP (150-200 cm) may be correlated with charcoal records from other sites in Southeast Asia that show peaks between 4000 and 2000 yr BP (Haberle et al., 2001). This peak is also correlative with pollen records from high elevation sites, Brass and Summit, Papua New Guinea (Flenley, 1996) that demonstrate the existence of forests at a lower elevation at that time. Therefore, the charcoal peak may be a regional event reflecting the development of dry climatic conditions (lower effective precipitation) with slightly lower atmospheric temperatures. 


\section{CONCLUSIONS}

The pollen and charcoal record from Rawa Danau, a tropical lowland swamp in West Java, Indonesia indicates:

1. Holocene vegetation changes occurred in the area as a response to climatic and environmental changes, as well as human disturbance.

2. The charcoal peak at 2300 3800 yr BP correlates with charcoal records from other sites in Southeast Asia. Therefore, this charcoal peak must have been caused by a regional event of dry climatic conditions (lower effective precipitation) with slightly lower atmospheric temperatures.

3. Changes in lignin phenols (LPVI values) of the Rawa Danau core were caused by changes in the relative abundance of Gramineae, rather than that of the gymnosperms.

ACKNOWLEDGEMENTS We are grateful to the Japanese Ministry of Education, Culture, Sports, Science and Technology for financial support. We also wish to thank Professor Kazuomi Hirakawa for allowing pollen preparation in his laboratory. This manuscript benefited from the suggestions of anonymous reviewers.

\section{REFERENCES}

Anderson, J.A.R., Muller, J. 1975. Palynological study of a Holocene peat and Miocene coal deposit from NW Borneo. Rev. Palaeobot. Palynol. 19: 291-351.

Caratini, C., Tissot, C. 1988. Palaeogeographical evolution of the Mahakam Delta in Kalimantan Indonesia during the Quaternary and Late Pliocene. Rev. Palaeobot. Palynol. 55: 217-228.

Flenley, J.R. 1996. Problems of the Quaternary on mountains of the Sunda-Sahul region. Quaternary Science Reviews 15: 549-555.

Haberle, S.G., Hope, G.S., Van der Kaars, S. 2001. Biomass burning in Indonesia and Papua New Guinea: natural and human induced fire events in the fossil record. Palaeogeography, Palaeoclimatology, Palaeoecology 171: 259-268.

Newsome, J., Flenley, J.R. 1988. Late Quaternary vegetational history of the central highlands of Sumatra-II. Palaeopalynology and vegetation history. J. Biogeography 15: 555-578.

Rimbaman. 1994. Penelitian pelestarian Rawa Danaudi Kabupaten Serang, Jawa Barat. Pusat Penelitian dan Penegmbangan Geologi dan Badan Perencanaan Pembangunan Daerah Propinsi Dati I, Jawa Barat. 40 pp. + appendices.

Stuijts, I. 1993. Late Pleistocene and Holocene vegetation of West Java, Indonesia. Modern Quaternary Research in Southeast Asia 12.

Stuiver, M., Reimer, P.J. Reimer 2000. Radiocarbon Calibration Program CALIB rev. 4.3 (Software Package).

Tareq, M.T., Tanaka, N., Ohta, K. 2004. Biomarker signature in tropical wetland: lignin phenol vegetation index (LPVI) and its implications for reconstructing the palaeoenvironment. Science of the Total Environment 324: 91-103.

Van der Kaars, W.A. 1991. Palynology of eastern Indonesian marine piston cores: a Late Quaternary vegetation and climate record for Australia. Palaeogeography, Palaeoclimatology, Palaeoecology 85: 239-302.

Van der Kaars, W.A. 1998. Marine and terrestrial pollen records of the last glacial cycle from the Indonesia region: Bandung Basin and Banda Sea. Palaeoclimates 3: 209-219.

Van der Kaars, W.A., Dam, M.A.C. 1995. A 135,000 yr record of vegetational and climatic change from the Bandung area, West Java, Indonesia. Palaegeogr. Palaeoclimatol. Palaeoecol. 117: 55-72.

Van der Kaars, S., Wang, X., Kershaw, P., Guichard, F., Setiabudi, D.A. 2000. A Late Quaternary palaeoecological record from the Banda Sea, Indonesia: patterns of vegetation, climate and biomass burning in Indonesia and northern Australia. Palaegeogr. Palaeoclimatol. Palaeoecol. 155: 135-153.

Van der Kaars, W.A., Penny, D., Tibby. J., Fluin, J., Dam, R.A.C., Suparan, P. 2001. Late Quaternary palaeoecology, palynology and palaeolimnology of a tropical lowland swamp: Rawa Danau, West-Java, Indonesia. Palaeogeog., Palaeoclimatol., Palaeoecol. 171: 185-212.

Yulianto, E., Sukapti, W.S., Rahardjo, A.T., Noeradi, D., Siregar, D.A., Suparan, P., Hirakawa, K. 2004. Mangrove shoreline responses to Holocene environmental change, Makassar Strait, Indonesia. Rev. Palaeobot. Palynol. 131: 251-268.

Received $30^{\text {th }}$ Sep. 2004 
Accepted $15^{\text {th }}$ Dec. 2004 